\title{
The Artist Image: How Do Children Depict Artists?
}

\author{
Aysegul Oguz \\ Correspondence: Assist. Prof. Dr. Aysegul Oguz, Elementary Education Department, Faculty of Education, Recep \\ Tayyip Erdogan University, Rize, Turkey
}

Received: July 21, 2015 Accepted: August 5, 2015 Online Published: October 9, 2015

doi:10.11114/jets.v4i1.1135

URL: http://dx.doi.org/10.11114/jets.v4i1.1135

\begin{abstract}
The aim of this study is to find out the artist image 5th grade elementary students have in their mind. Study group consisted of 60 students from the 5th grade elementary school in Rize province of Turkey during the 2014 instruction year. For data collection, an interview form was used consisting of 9 questions developed by researcher. An expert also revised the questions. The interview form was finalized in the light of comments provided by the expert. For the analysis of data, content analysis and descriptive analysis were used. Conclusion and recommendations were provided in the light of the study results. The findings show that students mostly define popular persons and singers as artists. As a result, it is suggested to offer an effective art education at all stages of education starting from pre-school.
\end{abstract}

Keywords: artist, artist image

\section{Introduction}

Art education is one of the courses that allow children to learn and experience the art. However, it can be said that art acquisitions are shaped with the stimuli with which children also interact outside lessons. Art education includes information on artists. The curriculum might be implemented in accordance with its purpose but it can be said that many factors play a role in shaping of artist images. It is important how students perceive artists. It can be argued that as 'artists' concept is considered, a popular singer will first come to the majority's mind. This perception can lead to students' developing missing, incorrect or negative attitude towards art and artists. Students first need to have a correct image of an artist in order to obtain benefits for artists. In this case, answer must be sought for the question "Who is an artist?" above all. There have been many definitions on the concept of artist. Some of these definitions are as follows: "The person who has creativity, produces a piece in any field of fine arts, art man, handicraftsman, artisan" (TDK, 2015). According to Pasin (2004: 13), the artist is "the person who is involved in productive activity in one of the arts and performs humane creation". In the question "What is an artist?" we are looking for the question "What should be the artist?" in essence. What is today's artist and artistic value? How many people have never heard of a popular singer in Turkey or have ever heard of Pablo Picasso? If it is zero, it is almost impossible that they compete with each other.

In the literature, pop music seems to be the most popular genre. Why do children always love pop music? It can be explained with its being easy to remember. Jazz or rock music genres may push the child's memory. Do mostly singers or popular names come to mind when the concept "artist" is called? We look at the concepts of art and artist first. A contemporary artist and leading academician, Pekmezci (2003) argues that in the essence of art lies the principle of editing, establishing a new order by bringing together in a different way what others did. He adds that art is a virtuous activity and one of the basic principles of art is the harmony between the elements forming an artwork.

Erişti (2010) studied the effect of popular culture on students' paintings and observed the influence of popular culture on majority of the paintings and the students use images of popular culture as a favourite theme. In their study, Sevim and Güleryüz (2012) found that prospective teachers have a high attitude towards popular music. In Özden and Barışeri's study (2010), it was seen that in relation with popular culture the students first recall current pop songs, TV series and competition programs. Also the most effective mass media used by students for following popular culture and music was found to be television and internet. In the research conducted by Yöndem (2013), certain recommendations were brought such as receiving effective music education starting from early ages against corruption in music, placing art education as an important course in schools, listening to music selectively and creating the habit of appreciation.

The perception regarding art and image of artist can be caused by many factors. "The leading factor causing corruption and contamination in music is mass communication" (Yöndem, 2013: 1044). Departing from this, it can be argued that mass communication often play an important role in formation of the children's taste in art. "Music teachers will be 
more successful if they develop their cultural capital in line with the right policy and ideology. Music teachers must evolve from the stereotype teacher who can read musical notes and sing songs into practitioners of music with the accumulation of intellectual knowledge and who can be applied for their knowledge" (Sakar, 2009: 392). In this regard, music teachers have major tasks to fulfil. It is crucial that the artists shaping the art history be recognized in the course of art education and be role models for children. It can be said that students sometimes identify the concept of artist with singers. Based on this assumption, it has arisen curiosity how children depict artists.

\section{Method}

60 students attending the $5^{\text {th }}$ grade in an elementary school in Rize Province participated in the study. The study was designed as qualitative research. As data collection instrument, an interview form comprised of 9 questions developed by researcher was used in this study. The questions in the interview form were revised by another expert and the final draft was prepared accordingly. According to Wiersma \& Jurs (2009: 237), "qualitative data analysis involves organizing and reducing of information". In this study, content analysis and descriptive analysis were used for analyzing the collected data. "What is essentially conducted in content analysis is to bring together similar data under certain concepts and themes and to edit and interpret them in a way readers can understand" (Yıldırım and Şimşek, 2006: 227). "The main objective of content analysis is to convert verbal/written materials and other materials into numeric data" (Tavşancıl and Aslan, 2001: 33). In this context, common codes obtained from students' views and drawings were determined, collected under common themes and displayed in tables by using frequency. "Descriptive analysis frequently includes direct quotations in order to reflect interviewed or observed individuals' views strikingly" (Yıldırım and Şimşek, 2006: 224). In this study also the views and opinions of the interviewees were quoted and their views were interpreted.

\section{Findings}

In this study, the participants' responses for the interview questions are displayed in tables below. Then, direct quotations from the participants' views are provided and they are interpreted.

Table 1. Imagine an artist and draw her/him.

\begin{tabular}{|c|c|c|}
\hline Theme & Code & Frequency (f) \\
\hline Facial expression & Happy & 45 \\
\hline \multirow[t]{8}{*}{ Accessories } & Hat & 5 \\
\hline & High heels & 4 \\
\hline & Belt & 4 \\
\hline & Strapless & 3 \\
\hline & Bracelet & 2 \\
\hline & Sunglasses & 1 \\
\hline & Neckwear & 1 \\
\hline & Bow tie & 1 \\
\hline \multirow[t]{4}{*}{ Painting materials } & Canvas & 22 \\
\hline & Brush & 18 \\
\hline & Palette & 13 \\
\hline & Paint & 2 \\
\hline \multirow[t]{8}{*}{ Music } & Microphone & 13 \\
\hline & Guitar & 6 \\
\hline & Musical note & 4 \\
\hline & Bağlama (string instrument) & 2 \\
\hline & Drum & 2 \\
\hline & Cello & 1 \\
\hline & Piano & 1 \\
\hline & Note book & 1 \\
\hline \multirow[t]{2}{*}{ Literature } & Book & 1 \\
\hline & Pen/pencil & 1 \\
\hline \multirow[t]{3}{*}{ Concepts related with other arts } & Camera & 4 \\
\hline & Sculpture & 3 \\
\hline & Theatre stage & 1 \\
\hline \multirow[t]{2}{*}{ Physical appearance } & Hair made & 14 \\
\hline & Make-up & 4 \\
\hline
\end{tabular}

The students were asked to imagine an artist and draw her/him in the scope of this question. The codes derived from their drawings were given in Table 1 under certain themes. When looked at the artists drawn by the students, it seems noteworthy that 45 students depicted a happy artist. Departing from here, it can be said that majority of the students assume that artists are cheerful people. It also attracts attention that majority of the students draw artists with painting materials such as canvas, brush and palette and music equipment such as microphone. It was observed that 14 of the 
students draw artists with hair made. Thinking popular arts, it can be said that the students determine the image of artists in that way. As regards to depiction of happy artists, the reason can be the fact that artists look happy in their video clips. Thus, the students might think that they enjoy their job. Below is given some of the drawings of artists by students along with the students' numbers and opinions regarding what depicted artists do:

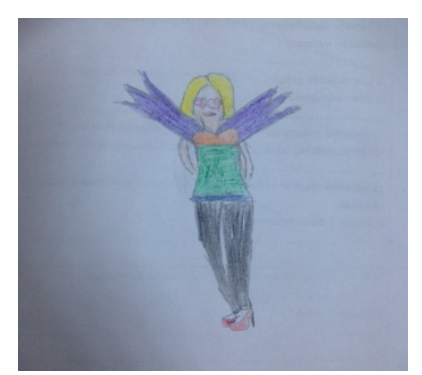

P1: "Giving a concert. At the same time singing and entertaining the audience."

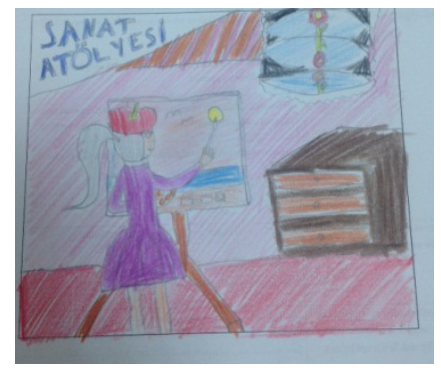

P35: "Painting in her own workshop, the studio she founded. Decorating her room with her paintings."

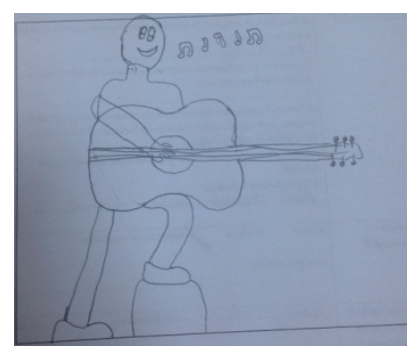

P38: "Making new music with a guitar of his own."

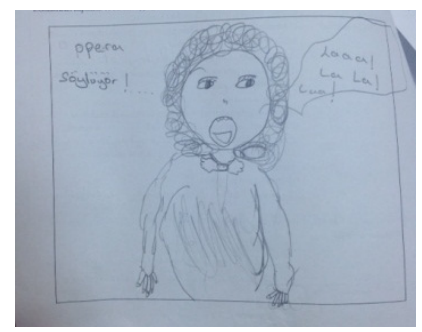

P13: "Located at a theatre hall. She sings opera there."

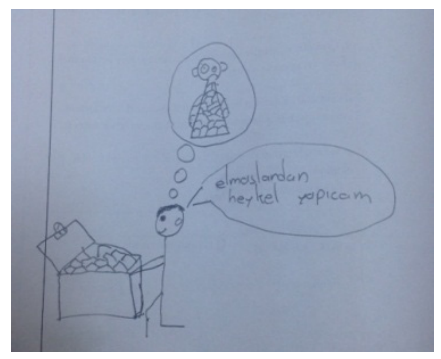

P50: "He usually makes sculpture, but not from stones or mud, he makes them from diamonds and he is so rich." 


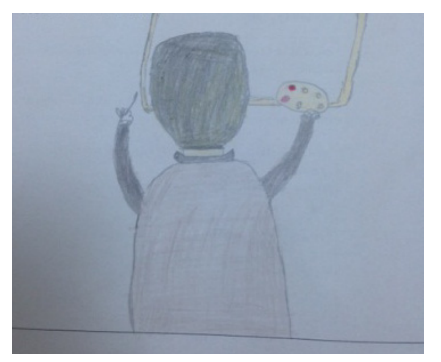

P55: "Artist at elementary school. He paints very nice pictures."

Table 2. What is the artist in your drawing doing?

\begin{tabular}{lll}
\hline Theme & Code & Frequency (f) \\
\hline Audial Arts & Singing & 12 \\
& Giving a concert & 5 \\
& Playing the guitar & 5 \\
& Composing a song & 3 \\
& Playing the piano & 1 \\
& Singing opera & 1 \\
& Playing the drum & 1 \\
& Playing the strings & 1 \\
\hline Plastic Arts & Painting & 22 \\
& Taking photos & 5 \\
& Making sculpture & 4 \\
\hline Literary Arts & Writing a book & 1 \\
\hline Performing Arts & Acting & 1 \\
\hline
\end{tabular}

The artists drawn by the students are grouped under four themes as audial, plastic, literary and performing arts. It was seen that majority of the students depict artists in the context of plastic arts as persons painting and audial arts as persons singing songs. Not appearing of other art branches can be related with inclusion of popular arts in daily life. How many people have sculptures or do not have any pictures in their homes? Pictures/paintings can exist in homes but sculptures can be rarer. Considering that art education courses mostly take place through painting than sculpture or other arts, it can be understandable that students link with painting more often than other arts. As for the students' statements concerning what the artists are doing in their drawings, some quotations are given below:

P3: “Giving a concert at a stage and so happy."

P10: "Playing the piano in her/his room, composing music."

From P18's statement "Drawing pictures on the table, exporting what is in her/his mind." It can be inferred that the participant believes art is an act of expression.

P21: "Doing landscape painting diligently."

Another participant, P24, links artists with being famous as far as understood from her/his statement "Singing at the stage and gaining fame."

P27: "Explaining the importance she gives to art in her home."

From P47 and P51's statements such as;

P47: "In Istanbul and singing."

P51: “A singer in Spain.”

It can be inferred that they regard art as an activity performed in large cities or countries. For example, depicted artists are not shown in the highlands of a small town or in a district. From this example, it can be inferred that students ascribe dealing with art to larger cities due to the potentials in such places.

P50's statement "He usually makes sculpture, but not from stones or mud, he makes them from diamonds and he is so rich" refers to the opinion that artists are rich. Due to their young age, the students may not know exactly the course of being an artist. As a conclusion, it can be said that they are product-oriented and they focus on the result.

Table 3. What is the gender of the artist you draw?

\begin{tabular}{ll}
\hline Gender & Frequency (f) \\
\hline Male & 35 \\
Female & 25 \\
\hline
\end{tabular}


35 of the students described a male artist and 25 as a female artist. Predominant depiction of artists as males can be related with taking place of mostly male artists in art history. Furthermore, it can be investigated whether students' choice at certain developmental stages have an influence.

Table 4. What is the age range of the artist you draw?

\begin{tabular}{ll}
\hline Age range & Frequency $(\mathrm{f})$ \\
\hline $10-20$ & 14 \\
$20-30$ & 31 \\
$30-40$ & 10 \\
$40-50$ & 4 \\
$50-60$ & 1 \\
60 and more & - \\
\hline
\end{tabular}

Majority of the students drew artists between ages of 20-30. It is interesting that no student marked the age range of 60 and above. The fact that the artists and the names in their depictions are largely young can be because they might have met young ones. They may have identified the youth with artistic personality. It may be since artists always appear young on television. When a famous artist is called, people might recall being above a certain age. Conversely, when popular art is concerned, the potential of being consumed quickly may come to the forefront and accumulation may not be in question since it is not related with transferring to the future.

Table 5. Write down the three words that come to your mind when the artist is called.

\begin{tabular}{|c|c|c|}
\hline Theme & Code & Frequency (f) \\
\hline \multirow[t]{8}{*}{ Painting } & Painting & 19 \\
\hline & Brush & 5 \\
\hline & Artist & 5 \\
\hline & Portrait & 2 \\
\hline & Paint & 2 \\
\hline & Palette & 2 \\
\hline & Landscape & 1 \\
\hline & Table & 1 \\
\hline \multirow[t]{7}{*}{ Music-related concepts } & Music & 11 \\
\hline & Singer & 7 \\
\hline & Song & 4 \\
\hline & Microphone & 1 \\
\hline & Pop & 1 \\
\hline & Sound & 1 \\
\hline & Concert & 1 \\
\hline \multirow[t]{8}{*}{ Concepts related to other arts } & Sculpture & 8 \\
\hline & Art & 3 \\
\hline & Artwork & 2 \\
\hline & Photograph & 1 \\
\hline & Cinema & 1 \\
\hline & Theatre & 1 \\
\hline & Stage & 1 \\
\hline & Acting & 1 \\
\hline \multirow[t]{21}{*}{ Personality traits } & Talented & 12 \\
\hline & Creative & 8 \\
\hline & Hardworking & 7 \\
\hline & Smart & 5 \\
\hline & Exciting & 3 \\
\hline & Art-lover & 3 \\
\hline & Intelligent & 3 \\
\hline & Kind-hearted & 3 \\
\hline & Joyful & 3 \\
\hline & Experienced & 3 \\
\hline & Curious & 3 \\
\hline & Idea owner & 2 \\
\hline & Patient & 2 \\
\hline & Unusual & 2 \\
\hline & Popular & 1 \\
\hline & Hardworking & 1 \\
\hline & Dynamic & 1 \\
\hline & Funny & 1 \\
\hline & Brave & 1 \\
\hline & Having good diction & 1 \\
\hline & Tolerant & 1 \\
\hline \multirow[t]{2}{*}{ Popularity } & Reputation & 5 \\
\hline & Interview & 1 \\
\hline Appearance-related properties & Charismatic & 5 \\
\hline
\end{tabular}




\begin{tabular}{lll}
\hline & Beautiful & 1 \\
Attractive & 1 \\
Arty & 1 \\
Nicely-dressed & 1 \\
Rich & 1 \\
\hline
\end{tabular}

The students were asked to note down three words that come into their mind as the artist is called. They were seen to frequently repeat terms such as painting, music, sculpture, singer, talented, creative and hardworking. The term "painting" was seen to have the highest frequency, which can be due to the fact that elementary students are closely connected with painting. Maybe music courses are not taught as effectively as art courses. Or maybe music lessons are restricted to playing the block flute in practice. Bearing in mind that students can access to materials and technical opportunities more easily than in other art branches, the finding can be understandable.

Considering that children are able to express themselves more easily starting from young ages also before exposure to formal education, again it can be normal that the concept of painting is repeated often. Children may be able to get more involved with music than painting. This can also be associated with the education they received. Furthermore, painting and music lessons might be carried out by non-expert teachers at elementary school, which might affect children's view about art.

Table 6. Who can you qualify as an artist around you?

\begin{tabular}{ll}
\hline Code & Frequency (f) \\
\hline My friend & 33 \\
My art teacher & 5 \\
My mom & 3 \\
Myself & 3 \\
My cousin & 2 \\
My dad & 2 \\
My music teacher & 2 \\
My teacher & 2 \\
Selçuk Balc & 2 \\
Tarkan & 2 \\
The people I see on TV & 1 \\
Everybody & 1 \\
Ajda Pekkan & 1 \\
Michel Telo & 1 \\
Cem Yilmaz & 1 \\
\hline
\end{tabular}

In relation with the person the students associate artists with, it was found out that majority of the students regard their friends as artists. They are followed by art teachers and mothers. The students' views are given below through direct quotations:

P1: "Mostly the people I see on television can be. They are also completely considered as artisans." The statement shows that the participant describes the people they see on television as artists at a high extent. It was added that still they may not exactly meet the concept of artist.

P24 related artists to being famous with the statement "Reputed, talented and skilful people are called artists."

P38 pointed out the importance of hard work for being an artist as understood from the statement "Anyone can be an artist by hard work.”

P49 stated "It is my art teacher because s/he is a very good painter and everybody loves her/his paintings." It can be said that the participant regards her/his art teacher as an artist because the latter is a good painter and her/his paintings are appreciated by all. It can be suggested that the student considers as a criterion being recognized and approved by others rather than oneself. In addition, it can be said that the participant considers it as a criterion to be accepted by the majority as a criterion.

\section{P50: "It is my art teacher, because my eyes become stuck there as I look at her/his paintings."}

From the point of view of P50, the teacher's being competent in painting can be a criterion. Otherwise, the student might be influenced from the art teacher's capabilities exceeding her/his own. The children might be taking those exceeding their capabilities as artists. The limited number of examples provided by students may be due to the absence of sample adults for artists. 
Table 7. Why?

\begin{tabular}{ll}
\hline Code & Frequency (f) \\
\hline Draws nice pictures & 33 \\
Sings beautifully & 8 \\
Plays the instrument beautifully & 4 \\
Acts well & 4 \\
Because s/he is funny & 3 \\
Sings opera nicely & 1 \\
Because I know her/him & 2 \\
S/he likes dancing & 1 \\
Anyone can be if s/he works hard & 1 \\
S/has beautiful video clips & 1 \\
Because s/he participated in the contest "You Are Talent(less)ed/" & 1 \\
\hline
\end{tabular}

When looked at Table 7, the reasons can be noticed for students' choosing certain persons around them as artists. It can be said that the most frequently used phrase 'drawing nice pictures' and the second most frequently repeated phrase 'singing beautifully' refer to exceeding one's capabilities. It could be argued that according to students, the more beautifully one can paint and sing, the closer she is to being an artist.

Table 8 . Who is (are) your favourite artist(s)?

\begin{tabular}{|c|c|c|}
\hline Theme & Code & Frequency (f) \\
\hline \multirow[t]{2}{*}{ Artist } & Leonardo da Vinci & 2 \\
\hline & Pablo Picasso & 2 \\
\hline \multirow[t]{12}{*}{ Foreign singer } & Katy Perry & 7 \\
\hline & Rihanna & 7 \\
\hline & Michel Telo & 7 \\
\hline & Justin Bieber & 3 \\
\hline & David Guetta & 3 \\
\hline & Shakira & 2 \\
\hline & Inna & 2 \\
\hline & Selena Gomez & 1 \\
\hline & Madonna & 1 \\
\hline & Michael Jackson & 1 \\
\hline & Anastacia & 1 \\
\hline & Beyonce & 1 \\
\hline Literature - Foreign Author & Jules Verne & 1 \\
\hline \multirow[t]{22}{*}{ Turkish singer } & Murat Boz & 13 \\
\hline & Tarkan & 12 \\
\hline & Hadise & 9 \\
\hline & Selçuk Balcı & 6 \\
\hline & Demet Akalın & 5 \\
\hline & Kolpa & 5 \\
\hline & Mustafa Ceceli & 4 \\
\hline & İsmail YK & 4 \\
\hline & Hande Yener & 3 \\
\hline & Mustafa Sandal & 2 \\
\hline & Karmate & 2 \\
\hline & Sertap Erener & 2 \\
\hline & Serdar Ortaç & 2 \\
\hline & Can Bonomo & 2 \\
\hline & Kenan Doğulu & 1 \\
\hline & Barış Manço & 1 \\
\hline & Atiye & 1 \\
\hline & Manga & 1 \\
\hline & Kazım Koyuncu & 1 \\
\hline & Seda Sayan & 1 \\
\hline & Murat Dalkılıç & 1 \\
\hline & Ozan Doğulu & 1 \\
\hline \multirow[t]{5}{*}{ Actor/Actress } & Çağatay Ulusoy & 2 \\
\hline & Kıvanç Tatlituğ & 1 \\
\hline & Cüneyt Arkın & 1 \\
\hline & Kemal Sunal & 1 \\
\hline & Meryem Uzerli & 1 \\
\hline
\end{tabular}

In Table 8, the students' favourite artist(s) can be considered from the popularity point of view. The fact that the students' 
favourite artists are involved in music can be explained with visibility of such persons. Again popular names are mentioned in relation with painters. In this context, Leonardo da Vinci's popularity might come from the coverage of art education classes and reading or seeing "Da Vinci Code" and reputation of the art work "Mona Lisa". Likewise, taking into account Pablo Picasso's being one of the most popular figures in art history, the participants' responses do not seem surprising. However, it might be noteworthy that Charlie Chaplin has never been mentioned despite being a popular person in the cinema. Also it is probable that books by Jules Verne were instructed at schools or students liked the books. It is seen that the singers such as "Murat Boz" and "Tarkan" have the highest frequency enquiring the respondents' favourite Turkish artists. Again popular names are mentioned in answers. The responses might reflect the appreciation of the people around the students or they might be related with environmental restrictions. Or, the singers that students are exposed to at home, at school or on school bus might affect the image of artist in their mind. The overall table implies that the names in responses represent the people who reflect the common enthusiasm and appeal to the general public.

The table also includes the actors/actresses playing in popular TV series. It might be due to parents' watching such TV series causing the children to be in interaction with those series. In addition, the TV channels suitable for children and TV programs which could develop children's socio-cultural value judgements might be scarce.

Table 9. Why?

\begin{tabular}{ll}
\hline Code & Frequency $(\mathrm{f})$ \\
\hline Her/His songs are beautiful & 20 \\
S/he sings beautifully & 18 \\
S/he is talented & 5 \\
I love her/him & 2 \\
S/he is modest & 2 \\
S/he can act well & 2 \\
I look like her/him & 1 \\
S/he has been involved with many things & 1 \\
S/he is the best painter & 1 \\
Her/His paintings are so beautiful & 1 \\
Most of her/his paintings are famous & 1 \\
I love this art & 1 \\
S/he is from Rize & 1 \\
S/he relaxes me & 1 \\
S/he is honest & 1 \\
S/he is famous & 1 \\
I am a fan of her/him & 1 \\
S/he looks good & 1 \\
I love her/his books & 1 \\
S/he is natural & 1 \\
\hline
\end{tabular}

Under this question, the students' explanations regarding what they like about their favourite artists are given in a table. When asked why those artists are their favourite, most often it was said that they have beautiful songs, they sing beautifully and they are talented. The students may have expressed in different ways that they enjoy their songs. It is already mentioned in Table 8 that mostly popular names are mentioned. For example, jazz music can be considered to be good but may not be popular. The children might prefer something they love merely because they are funny for them. The children cannot assess these works and artists against actual art or artist criteria. While determining their favourite artists, the children might be influenced from the factor that such artists are able to do more than what they are able to. Considering children's age-related characteristics and knowledge, it can be commented that the students refer to figures based on giving them more joy and pleasure instead of artistic criticism techniques.

Children have fun with it at the same time. They do the things because they enjoy doing. One can argue that giving joy and pleasure is important to be nice to them since children have no intellectual concerns due to their age characteristics. "Not only the education of the producer of art but also the art consumer's (receiver) level and nature of encountering with art during formal or non-formal education is important" (Öztürk, 1994: 64). Students' explanations regarding their favourite artists are given below through direct quotations:

P6's statement "Leonardo da Vinci was involved with everything” might be emphasizing the wide range of interests and capabilities of Leonardo da Vinci.

P15's statement "Barış Manço, because he was honest and talented" seems to support the table above indicating the association of the concept of artist with talent.

P18's statement "Hadise, she is famous and has beautiful songs" and P28's statement "Hande Yener, she has a beautiful voice and sings beautifully" also seem to be supportive of the frequently repeated code regarding singing 
beautifully in the table above.

\section{P36: “Kıvanç Tatlıtuğ, he acts well”}

P50: “Picasso, many works of him are famous, I like his paintings"

P54: “Murat Boz, because he sings so beautifully and does very nice gestures." The explanation might be emphasizing the singer's stage performance.

Apart from these above, the participant P58 noted "Tarkan, he has performed the arts accurately and so nicely", which might refer to the singer's dealing with distinct musical genres such as Turkish classical music and pop music as a professional.

It is seen in the views cited above that being famous and popular is generally associated with singing beautifully, painting pictures and acting. The students seem to avoid giving only one reason. It can be interesting that they make two sentences to support the artistic personality.

\section{Conclusion and Recommendations}

According to an overall evaluation of the research findings, it can be said that students mostly describe popular singers and frequently appearing on television as artists. The research showed that majority of the participants drew a happy artist. Also it is remarkable that majority of the students depict the artist with painting materials such as canvas, brush and palette; or microphone as musical equipment. In the context of popular arts, the students can be said to identify the image of artist in the way popular art is introduced to them in their daily life. The students depicted the artists as persons that are painting under the theme of plastic arts and persons singing under the theme of audial arts. The lack of other art branches can be connected with popular arts' taking part in daily life. Hence, it can be said the students have established connections with painting more than any other art.

35 of the students described a male artist and 25 as a female artist. It is commented that artists are predominantly depicted as males as they take most place in art history. Majority of the students drew artists between ages of 20-30. It draws attention that none of the student marked the age range of 60 and above. The artists and the names in depictions are largely young people because the students might have met young artists so far. Under the three words that come to their mind as the artist is called, the students mentioned the terms such as painting, music, sculpture, singer, talented, creative and hardworking with highest frequency. There might be a relationship between referring to persons involved in popular music as favourite artists and such persons' constantly being in mind. Similarly, popular names are given in relation with painters. Having a look at the students' favourite Turkish artists, "Murat Boz" and "Tarkan" have revealed the highest frequency. The responses include popular names in this case, too. Besides, some of the actors/actresses taking part in popular TV series are seen. Regarding the reason why certain artists are their favourite artists; beautiful songs, singing beautifully and being talented were founded to be the most frequently cited reasons.

In the light of the study results, it can be suggested that television programmes should be integrated with universal value judgements besides producing social value judgements. We can say that singers take much part in television programmes. Thus, the artists shaping the art history should take at least as much part as singers in television programmes. As an example, important artists such as Pablo Picasso or Leonardo da Vinci should be able to appear on television programmes as much as singers, even more than singers do. The children might perceive singers as artists because families use the technology for their own preference causing the culture of children likened to the family's culture. In schools, formally greatest artists in the history of art may be taught in arts education classes, but children learn popular singers they see on TV during informal education. In conclusion, it is recommended to give effective arts education at all levels starting from pre-school.

\section{References}

Erişti, S. D. (2010). Primary school students' popular culture perception in their pictures (The Example of Multicultural Fjell Primary School in Norway). Ilkögrretim online, 9(3), 884-897, 2010. http://ilkogretim-online.org.tr

Özden, Ö., \& ve Barışeri, N. (2010). The opinions of university students about popular culture and popular music. E-Journal of New World Sciences Academy, 5(4), 276-294.

Öztürk, R. (1994).The relationship between the level of interest in arts and the democratic attitudes. Master thesis, Ankara University, Ankara.

Pasin, G. (2004). Lise sanat etkinliklerini izleme 11. sınıf. İstanbul: MEB Yayınları.

Pekmezci, H. (2003). Anadolu güzel sanatlar liseleri içim desen. Ankara: MEB Yayınları.

Sakar, M. H. (2009). Popular music and music education. The journal of international social research, 2(8), $385-393$.

Sevim, O., \& ve Güleryüz, Ş. (2012). Attitudes of teacher candidates toward popular music. Atatürk University Journal 
of Graduate School of Social Sciences, 16(1), 199-210.

Tavşancıl, E., \& ve Aslan, A. E. (2001). Sözel, yazılı ve diğer materyaller için içerik analizi ve uygulama örnekleri, İstanbul: Epsilon Yayıncılık.

TDK(2015).http://www.tdk.gov.tr/index.php?option=com_bts\&arama=kelime\&guid=TDK.GTS.54f9a73e71c979.9407 4936

Wiersma, W., \& Jurs, S. G. (2009). Research methods in education an introduction, Boston: Pearson.

Yıldırım, A., \& ve Şimşek, H. (2006). Qualitative research methods in social sciences. Ankara: Seçkin Publishing.

Yöndem, S. (2013). Corruption in the music effect of globalization. International Journal of Social Science, 6(2), 1043-1051.http://dx.doi.org/10.9761/jasss_584

\section{(cc) $\mathrm{EY}$}

This work is licensed under a Creative Commons Attribution 3.0 License. 